\title{
Implementation of Cleanliness, Health and Environmental Sustainability Guidelines in Restaurants around the Southern Java Crossing Route in Ciamis Regency
}

\author{
Ita Maemunah \\ Sekolah Tinggi Pariwisata Bandung, Indonesia \\ itm@stp-bandung.ac.id
}

\begin{abstract}
This study aims to determine the extent to which restaurants on the southern route of Java in Ciamis district implement standard health protocols for Cleanliness, Health, Safety and Environmental Sustainability (CHSE) in order to prevent the spread of the COVID-19 outbreak. This standard health protocol refers to the health guidebook in hotels and restaurants (CHSE) that has been issued and published by the Ministry of Tourism and Creative Economy. This research was conducted as a measuring tool as a control reference in the implementation of the CHSE health protocol, especially in restaurants in the southern route of Java, Ciamis district. This study used a survey research method approach with data collection techniques through interviews; observation, and literature study. The population in this study were restaurants located on the southern route of Java in Ciamis Regency with a non-random sampling technique, namely accidental sampling. The results of this study indicate that the implementation of general guidelines and specific guidelines for CHSE health protocols is still not going well.
\end{abstract}

Keywords

Implementation of CHSE;

restaurants

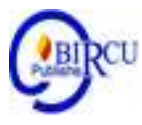

\section{Introduction}

In 2020 is a year that will be in history as a year of world crisis. The whole world is being faced with a precarious situation which has resulted in the economy in various parts of the world being hampered by a new epidemic that is widespread. Until now, conditions in various countries have not improved due to the absence of a vaccine for this epidemic. On January 30, 2020, the World Health Organization or shortened to WHO announced an outbreak of a new coronavirus or often known as COVID-19, which originated in China, precisely in the city of Wuhan, which then spread to international levels. COVID-19 is a disease that was not previously identified in humans, it is a group of viruses found in animals. The corona virus is known to spread most easily through close contact with an infected person, it can spread through coughing or sneezing and it can entry through breathing if too close to an infected person. For people who have been infected with COVID-19, these symptoms will appear and if not handled properly it will cause death. WHO calls for restrictions on each other and advises to stay at home and avoid large crowds. In Indonesia, the spread of COVID-19 has spread to all 34 provinces with the most cases in the capital city DKI Jakarta, which reaches $25.8 \%$ of the total 33,076 confirmed cases of COVID-19. For several large areas and its surroundings have implemented large-scale social restrictions that urge people to work and activities at home, which has had a negative impact on several sectors. The impact of this large periodic social restriction caused the entire education sector to stop operating and public facilities 
were closed. Various health protocols have been issued by the government to obtain this limited activities.

The economy and business sector is no exception, which is hampered and even forced to close due to lack of income to survive in this pandemic era. The tourism industry must prepare itself to be able to guarantee high hygiene, health, safety and environmental sustainability for the products and services provided to tourists. Therefore, the Ministry of Tourism and Creative Economy / Tourism and Creative Economy Agency (Kemenparekraf) published a guidebook on health protocols Cleanliness, Health, Safety and Environmental Sustainability (CHSE) in hotels and restaurants at Hotel Borobudur, Monday (13/7/2020). This book is a practical guide for the tourism industry in preparing products and services that are clean, healthy, safe and environmentally friendly, especially hotels and restaurants.

Restaurant service or commonly referred to as food \& beverage or food and beverage in the hotel industry is a service business that aims to meet the needs of providing food and beverage and other needs in restaurants. "A restaurant is a profitable food service operation whose main basis includes the sale of food or drink to individuals and small group guests" (Ninemeier and Hayes: 2006). In restaurant service, the key to this service is the serving of food and drinks to guests. Some restaurants have adapted by implementing new health protocols in service in order to survive. The implementation of these health protocols certainly adds to new expenses which do not rule out the implementation of these health protocols that are not in accordance with the CHSE health protocol standards. Ciamis Regency as one of the regencies in West Java province, is located in the north bordering the Regency

Majalengka and Kuningan districts, to the west with Tasikmalaya and Tasikmalaya cities, to the east with Banjar cities and Central Java Province, and to the south with the Indonesian Ocean. Based on its geographic location, Ciamis Regency is in a strategic position that is traversed by the National road across West Java Province, Central Java Province and the provincial road crossing Ciamis - Cirebon - Central Java. Ciamis Regency itself is passed by the Java crossing which is known as the southern route. This strategic position makes Ciamis Regency vulnerable to the development of COVID-19 transmission, because the flow of human movement using 2-wheeled, 4-wheeled transportation, and even public transportation such as buses, makes Ciamis Regency a stopover point. People who are traveling either to West Java or to Central Java via the southern route certainly need a place to stop for a good rest, eating, drinking, worshiping, and others. To meet their consumption needs, they will certainly stop at the restaurants available on the southern route, especially in the area around Ciamis district. Based on data obtained from PHRI Ciamis, there are 280 restaurants and restaurants in Ciamis Regency. The implementation of the CHSE health protocol is very important for these restaurants to prevent the transmission of COVID- 19 of the migrants who stopped by, especially the migrants from the red zone and the yellow zone. The application of this protocol must be applied consistently and well to all visitors, considering that according to health experts, transmission is difficult to detect because many people with COVID-19 do not show symptoms or are often called People Without Symptoms (OTG). Based on this, the research team will conduct research to help the government in a control role in the implementation of the CHSE health protocol, especially for services in restaurants around Ciamis Regency, especially restaurants on the Southern Java Crossing Line. 


\section{Review of Literature}

\subsection{Restaurants}

A restaurant is a facility for all activities related to the sale or transaction of food and / or beverages where services and goods serve as selling points to serve customers. In another sense, a restaurant or it can be called a restaurant is a place to serve dishes to customers and provide a place to enjoy a meal and apply certain rates for food or beverages and services. "A restaurant is a food service operation that brings profit, whose main basis is included in it. is the sale of food or drink to individuals and guests in small groups "(Ninemeier and Hayes: 2006).

\subsection{Standard Operational Procedurs}

Standard operating procedures are guidelines that are used to ensure that the operational activities of an organization or company run consistently, effectively, efficiently, systematically and well managed" (Airini T Soemohadiwidjojo: 2004). From the definition above, standard operating procedure or commonly abbreviated as SOP is a guide for workers in carrying out their duties in an organization or company. With the existence of an employee performance SOP that will be in accordance with what the company wants, this SOP makes the activities of a job fast, efficient, effective and precise with the steps listed in the SOP for

complete an organization or company activity.

\subsection{New Normal}

New Normal" or the new normal era is an environment where various possibilities will exist for those who want to play with new rules for the long term "(Roger Mc Namee (2003). At this time the world is experiencing a pandemic caused by the corona virus or better known. COVID-19, an expert who is the government's spokesperson in accelerating the handling of COVID 19 outlined an understanding of the new normal era. "The new normal is a new life order defined as a productive and safe life from the corona virus outbreak" (Achmad Yurianto). above normal, is a concept where there is a renewal of habits and activities in daily life which is caused by a crisis condition that requires updating all things that are usually done with a limit to be able to meet the criteria of being safe from this crisis condition.

The new normal occurs due to certain conditions that require changing habits, for now the new normal is caused by COVID 19 or the corona virus and requires people to follow health protocols. The World Health Organization or WHO has set several conditions before being able to implement the new normal, which are as follows:

a) Ensure controlled transmission. b) The health system is in a state good.

c) Guaranteed preventive measures in the work environment.

d) Prevent imported cases of COVID 19.

e) Ensuring public awareness and participation.

\subsection{Guidelines for the Implementation of Cleanliness, Health, Safety and Environmental Sustainability in Restaurants / Restaurants \\ In order to implement health protocols for productive communities for the prevention} and control of Corona Virus Disease 2019 (Covid-19), in July 2020, the Ministry of Tourism and Creative Economy / the Indonesian Tourism and Creative Economy Agency has issued Guidelines for the Implementation of Cleanliness, Health, Safety and Environmental Sustainability in Restaurants / Restaurants, in the face of a new normal era for activities as usual. 
The Implementation Guide for Cleanliness, Health, Safety and Environmental Sustainability (CHSE) or hereinafter referred to as the Implementation Guide for Cleanliness, Health, Safety and Environmental Sustainability in Restaurants / Restaurants is an operational guide from the Decree of the Minister of Health Number HK.01.07 / Menkes / 382/2020 on Health Protocols for the Community in Public Places and Facilities in the Context of the Prevention and Control of Corona Virus Disease 2019 (Covid-19). This guide is intended for entrepreneurs and / or managers and employees in meeting guests' needs for clean, healthy, safe and environmentally friendly tourism products and services during the Covid-19 pandemic. This guide can also be a reference for Provincial Governments, Regency / City Governments, as well as business and professional associations related to restaurants / restaurants to conduct socialization, tutorials / education, simulations, trials, assistance, guidance, monitoring and evaluation in the implementation of cleanliness, health, safety and environmental sustainability, in order to increase the confidence of the parties, business reputation and tourism destinations.

The provisions contained in this guide refer to the protocols and guidelines established by the Government of Indonesia, the World Health Organization (WHO), and the World Travel \& Tourism Council (WTTC) in the context of preventing and handling Covid-19. The preparation of the guidelines involved various parties, namely restaurant / restaurant business associations, professional associations related to the restaurant / restaurant sector, and academics. The subject matter contained in the Health Guide of the Ministry of Tourism and Creative Economy / the Indonesian Tourism and Creative Economy Agency is divided into 2, namely General Guidelines and Special Guidelines according to the flow of restaurant / restaurant services.

\section{Research Methods}

The approach in this research is a qualitative research method. According to Moleong (2010) qualitative research is research that intends to understand the phenomena experienced by research subjects such as behavior, perception, motivation, action, etc. holistically and descriptively in the form of words and language in a specific context. naturally and by making use of various scientific methods. The data collection technique was done using interviews, observation and literature study, while the population taken was restaurants around Ciamis Regency with a non-random sampling technique, namely accidental sampling of 20 restaurants. The data that has been collected is then further analyzed to obtain results that are used as answers to research problems using in-depth data analysis techniques or what is called in-depth analysis with steps of data reduction, data presentation, and drawing conclusions.

\section{Discussion}

The southern Java route, Ciamis Regency, West Java, is one of the routes that connects West Java and Central Java. This route is often used by people who want to travel to the central and / or eastern parts of Java or vice versa, namely to the western part of Java, either using large vehicles such as buses, trucks and the like, or even small vehicles such as city cars to cities motorcycle.

The people traveling through the southern Java route, Ciamis district, are not only people who come from West Java, but also many people who come from other provinces such as DKI Jakarta province, Banten province, Central Java province, province East Java, even people from the island of Sumatra also use this route as a crossing to the central and 
eastern parts of Java or even vice versa, namely towards the western part of Java to Sumatra. Researchers can find this out by looking at the area code on the number plates of motorized vehicles passing on this route and based on the results of interviews with employees of restaurants around the southern route of Java, Ciamis district, West Java.

Because the southern route of Java, Ciamis Regency, West Java, is an active route that is widely used by motorists, therefore many people around Ciamis take advantage of this route by establishing rest areas that facilitate motorists to rest from a long tiring journey. This resting area is usually provided restaurants / restaurants, public toilets, places of worship / prayer rooms and others.

After the researchers made a checklist for the implementation of health protocols according to the CHSE guidelines for restaurants / restaurants based on the guidebook for health protocols Cleanliness, Health, Safety and Environmental Sustainability (CHSE) from the Ministry of Tourism and Creative Economy / the Tourism and Creative Economy Agency (Kemenparekraf / Baparekraf) ) above, the researcher outlines the assessment as follows:

Table 1. Implementation of Guidelines for Implementation of Hygiene, Health, Safety and Environmental Sustainability Protocols in Restaurants - Restaurants Around the Southern Java Route in Ciamis Regency

\begin{tabular}{|l|l|l|l|}
\hline No & \multicolumn{1}{|c|}{ CHSE GUIDE } & \multicolumn{1}{|c|}{ Already implemented } \\
\cline { 3 - 4 } & & \multicolumn{1}{|c|}{ Yes } & \multicolumn{1}{|c|}{ No } \\
\hline 1 & General guidance for management & $48,91 \%$ & $51,09 \%$ \\
\hline 2 & $\begin{array}{l}\text { General guide for employees, guests, and other parties } \\
\text { who are active in the restaurant }\end{array}$ & $62,5 \%$ & $37,5 \%$ \\
\hline 3 & A special guide for entrepreneurs in the entrance area & $34,44 \%$ & $65,56 \%$ \\
\hline 4 & A special guide for guests in the entrance area & $46,25 \%$ & $53,75 \%$ \\
\hline 5 & Specific guidelines for employees in the entrance area & $63,33 \%$ & $36,67 \%$ \\
\hline 6 & Specific guidelines for entrepreneurs in the service area & $65 \%$ & $35 \%$ \\
\hline 7 & Special guide for guests in the service area & $81,67 \%$ & $18,33 \%$ \\
\hline 8 & Specific guidelines for employees in service areas & $43,75 \%$ & $56,25 \%$ \\
\hline 9 & $\begin{array}{l}\text { A specific guide for entrepreneurs in the payment area and } \\
\text { the exi }\end{array}$ & $33 \%$ & $67 \%$ \\
\hline 10 & Special guidance for guests in the payment area and exits & $15 \%$ & $85 \%$ \\
\hline 11 & $\begin{array}{l}\text { A specific guide for employees in the payment area and } \\
\text { the exit }\end{array}$ & $33,33 \%$ & $66,67 \%$ \\
\hline 12 & A specific guide for businessmen in the kitchen area & $71,79 \%$ & $28,21 \%$ \\
\hline 13 & A specific guide for employees in the kitchen area & $77,5 \%$ & $22,5 \%$ \\
\hline 14 & $\begin{array}{l}\text { A special guide for entrepreneurs in the administration } \\
\text { room area }\end{array}$ & $45,71 \%$ & $54,29 \%$ \\
\hline 15 & $\begin{array}{l}\text { Special guidance for employees in the administration } \\
\text { room area }\end{array}$ & $77,5 \%$ & $22,5 \%$ \\
\hline 16 & $\begin{array}{l}\text { Specific guidelines for employers in the employee room } \\
\text { area }\end{array}$ & $40,83 \%$ & $59,17 \%$ \\
\hline 17 & $\begin{array}{l}\text { Specific guidelines for employees in the employee room } \\
\text { area }\end{array}$ & $70 \%$ & $30 \%$ \\
\hline
\end{tabular}


Based on a number of research results that have been described above, it is known that the restaurants / restaurants in the southern route of Java, Ciamis Regency, West Java have not entirely implemented health protocols properly according to the health protocol guidebook Cleanliness, Health, Safety and Environmental Sustainability (CHSE). from the Ministry of Tourism and Creative Economy / Tourism and Creative Economy Agency (Kemenparekraf / Baparekraf). From the results of the percentage of the assessment, as much as $51.09 \%$ of restaurant management has not implemented the General Guidelines for the Implementation of Cleanliness, Health, Safety, and Environmental Sustainability in Restaurants / Restaurants. Only as big as $48.91 \%$ who have applied.

The form of implementing general guidelines for employees, guests, and other parties who are active in the restaurant is applied when guests enter the restaurant area, in the form of a notification banner regarding the most basic health protocols, such as requiring the use of masks and washing hands before entering the restaurant area. The average restaurant in Ciamis district has done this, which is equal to $62.5 \%$. Special guidelines in the entrance area for guests have been implemented in $46.25 \%$ of restaurants in Ciamis Regency, while $53.75 \%$ have not implemented this. Checking body temperature at the entrance is still rarely done because limited equipment provided by restaurant management. The percentage of implementing special guidelines for guests in the service area was $63.33 \%$, while $36.67 \%$ had not been implemented. The service area, especially the guest table, is given a limit / distance per seat and some restaurants reduce the number of seating capacity according to the physical distancing appeal standard.

Special guidelines for guests in the service area $81.67 \%$ have been implemented, because every restaurant in Ciamis district is a restaurant with a traditional Sundanese concept so that every corner has prepared facilities for washing hands with clean water and soap. This has become the standard of Sundanese restaurants even before the Covid-19 pandemic took place. In Payment Areas and exits, 85\% have implemented health and security protocols by providing hand sanitizers at the cashier desk. Cashiers are also required to wear a mask when making transactions with consumers. In terms of implementing special guidelines for employers in the employee room area, as many $40.83 \%$ of restaurants / restaurants in the southern route area of Java, Ciamis Regency, West Java have implemented it and many $59.17 \%$ have not applied according to the standards in the guidebook. This can be seen from the special employee areas provided by employers that are not in accordance with standard guidelines and employers do not provide information or advice to their employees regarding the implementation of cleanliness standards in the employee room area.

Based on the results of the above discussion, the average restaurant / restaurant in the southern route of Java, Ciamis Regency, West Java that has implemented the general guidelines for health protocols is equal to $52.42 \%$, the remaining $47.58 \%$ have not implemented according to the health protocol guidelines. Meanwhile, it is average. There are $54.13 \%$ of restaurants / restaurants in the southern route of Java, Ciamis Regency, West Java, while the remaining $45.87 \%$ have not implemented the guidelines for health protocols.

The implementation of good health protocols and according to the standard CHSE health protocols in every restaurant / restaurant will make consumers feel safer and more comfortable in them when resting or enjoying the food and beverage offerings provided. Apart from consumers, residents around the restaurant / restaurant will feel safe and calm. When restaurant / restaurant management applies good and standard health protocols, it is also an excellent form of support for the Indonesian government's program to stop the spread of the COVID-19 virus in this country. Even though the area of Ciamis district, West Java is a green zone when research is carried out, the COVID-19 virus will be easily 
spread to residents of Ciamis district, West Java, especially residents around the southern Java route, Ciamis district, West Java due to exposure to people. who come to stop at restaurants or restaurants along the route.

\section{Conclusion}

The implementation of the general guidelines for the CHSE health protocol in restaurants around the Southern Java route in Ciamis district is still not going well. The general guidelines for health protocols are more on activities and service activities both from internal and external parties. This service activity opens the possibility of interaction between individuals, so that it can be a way of transmitting the Covid19 virus from human to human. Less the implementation of these general guidelines tends to be due to a lack of public awareness of the importance of preventive measures, a lack of knowledge of information about the transmission system and the spread of the Covid19 virus, at least instructions and markings regarding the provisions of health protocols, and also the absence of supervision from related parties, both from the civil service unit. praja, health service, tourism office, or local trade service. The level of awareness and compliance of the public and restaurants is still quite low, so that the application of general guidelines tends to loosen up as the loosening of zoning regulations in many areas has resulted in higher community movement.

The CHSE health protocol also contains specific guidelines that regulate the activities of service providers, which in this case are restaurant employees in an area. This is also considered important considering the resistance of viruses both in the air and when attached to something for a long time. The results of research on the implementation of the special guidelines for the CHSE health protocol in restaurants around the southern Java route in Ciamis district show that there are still many restaurant employees who do not apply the protocol properly. Actually, the government itself has given special rules as a condition for allowing restaurant entrepreneurs to reopen their businesses. The rules related to the health protocol have been implemented and applied. However, again, the level of awareness of restaurant employees is quite low. Supervision and evaluation are rarely carried out by restaurant managers on their employees. Even so, there are also managers who are quite creative in their efforts to maintain consistency in the implementation of the protocol by placing tags that attract enough attention.

For the restaurant manager, it is hoped that they will be able to overcome the inconsistency problem of their employees by implementing good supervision techniques, periodic evaluations, and adding supporting facilities for health protocols in their restaurants. For the local government, it is hoped that they will continue to provide strict supervision regarding the implementation of health protocols, as well as to implement strict sanctions for restaurants that violate them, so that they can become an example for other restaurants to remain disciplined. In addition, the government should also continue to support restaurant business activities by providing direction and education on the importance of maintaining health protocols for all restaurant business actors including employees. For the police law apparatus to continue to guard the border areas by continuing to educate the people passing through not to travel without a destination and purpose that really matters. For the Satpol PP apparatus to always be in the field to always educate the public regarding the importance of keeping yourself healthy and always using a mask. Restaurant employees are expected to always comply with health protocols while working and interacting with other people, and dare to discipline guests so that they always comply with health protocols. 


\section{References}

Arini T. Soemohadiwidjojo. (2014). Mudah Meyusun SOP (Standard Operating Procedure): Penebar Plus.

Kementerian Pariwisata dan Ekonomi Kreatif/ Badan Pariwisata dan Ekonomi Kreatif (Kemenparekraf) menerbitkan buku panduan protokol kesehatan di bidang hotel dan restoran

Keputusan Menteri Kesehatan Nomor HK.01.07/MENKES/328/2020 tentang Panduan Pencegahan dan Pengendalian Covid-19 di tempat kerja perkantoran dan industri

Kotler, Philip \& Gerry Armstrong, (2014). Principle of Marketing, 15th edition. NewJersey: Pearson Pretice Hall.

Moelong, L. (2017). Metodologi Penelitian Kualitatif. Cet.ke-36. Bandung: PT. Remaja Rosdakarya.

Ninemeier, J.D. \& D.K. Hayes. (2006). Hotel Operations Managament. Upper Saddle River, NJ: Pearson Education, Inc

Panduan protokol kesehatan Cleanliness, Health, Safety and Environmental Sustainability (CHSE)PERMENPAN PER/21/M-PAN/11/2008

Sugiyono. 2015. Cara Mudah Menyusun: Skripsi, Tesis, dan Disertasi. Bandung: CV. Alfabeta.

Soekarno, \& Pendit. (1998). Pramusaji Food \& Beverage Service. Jakarta: PT Gramedia Pustaka Utama https://www.tripadvisor.co.id/Restaurants-g3310650-

Ciamis_West_Java_Java.html/. 